\title{
Severe Iatrogenic Calcinosis Cutis From Extravasated Calcium Gluconate
}

\author{
Brad E. Rumancik $^{1}$, Sahand Rahnama-Moghadam ${ }^{1}$ \\ 1. Dermatology, Indiana University School of Medicine, Indianapolis, USA
}

Corresponding author: Sahand Rahnama-Moghadam,srahnama@iupui.edu

\begin{abstract}
Iatrogenic calcinosis cutis occurs when insoluble calcium salts deposit in cutaneous and subcutaneous tissue. Iatrogenic calcinosis cutis is a rare complication from a variety of medical interventions, most commonly due to extravasated intravenous calcium-containing solutions. We present a severe case of iatrogenic calcinosis cutis in a patient with end-stage renal disease and an elevated serum calciumphosphate product. Iatrogenic calcinosis cutis has a wide range of clinical presentations. Either subclinical or clinically noticeable extravasations may cause mild to severe calcinosis cutis. Patients with increased serum calcium and phosphate may be at increased risk of iatrogenic calcinosis cutis. Treatment options include conservative, pharmacologic, or surgical management.
\end{abstract}

Categories: Dermatology, Internal Medicine, Nephrology

Keywords: iatrogenic calcinosis cutis, dystrophic calcification, extravasation, calcium gluconate, calcium chloride

\section{Introduction}

Calcinosis cutis is defined as insoluble calcium salt deposition in cutaneous and subcutaneous tissue [1,2]. There are five subtypes of calcinosis cutis based on etiology: dystrophic, metastatic, calciphylaxis, idiopathic, and iatrogenic. Dystrophic calcinosis cutis is due to local tissue damage secondary to trauma, infection, neoplastic processes, or a variety of connective tissue disorders. Metastatic calcinosis cutis, a rare manifestation, occurs secondary to systemic calcium and phosphate abnormalities, classically occurring in chronic renal failure. Calciphylaxis, a related yet distinct entity from metastatic calcinosis cutis, occurs when small and medium-sized blood vessels in the dermis and subcutaneous fat calcify. Idiopathic calcinosis cutis occurs without known local tissue injury or metabolic disorders [1,2]. Lastly, iatrogenic calcinosis cutis most commonly occurs from extravasation of calcium or phosphate-containing solutions [3]. Iatrogenic calcinosis cutis has been reported in patients undergoing electroencephalography or electromyography with prolonged periods of exposure to saturated calcium-containing electrode paste [4-6]. Iatrogenic calcinosis cutis has also occurred in patients receiving subcutaneous injections of para-aminosalicylic acid, solid organ transplant recipients, and neonates receiving numerous heel venipuncture sticks [1,2]. We present a severe case of iatrogenic calcinosis cutis after extravasation of calcium gluconate solution.

Received 07/27/2020

Review began 07/29/2020 Review ended 08/08/2020 Published 08/13/2020

(c) Copyright 2020

Rumancik et al. This is an open access article distributed under the terms of the Creative Commons Attribution License CC-BY 4.0., which permits unrestricted use, distribution, and reproduction in any medium, provided the original author and source are credited.

\section{Case Presentation}

A 55-year-old woman with no underlying connective tissue disease and a past medical history of hemodialysis-dependent end-stage renal disease due to type 2 diabetes mellitus and hypertension was hospitalized for left lower extremity cellulitis who requested inpatient removal of a right forearm plaque. The lesion location corresponded with the site of an extravasated calcium gluconate peripheral intravenous infusion, which was administered 13 days prior during a previous hospitalization requiring urgent hemodialysis to treat hyperkalemia. The patient described an initial burning sensation during the extravasation, but the subsequent calcification, which developed over a few days, was insensate.

On examination, a yellow-white, rock-hard indurated plaque measuring approximately $4 \times 3 \mathrm{~cm}$ with overt mineral deposits was found on the right distal flexor forearm (Figure 1). The bandage next to the lesion in question is to remedy an unrelated trauma-induced injury. At the time of physical examination, her serum corrected calcium level was $10.1 \mathrm{mg} / \mathrm{dl}$ (normal range: $8.5-10.1 \mathrm{mg} / \mathrm{dl}$ ) and phosphate level was $7.6 \mathrm{mg} / \mathrm{dl}$ (normal range: $2.5-4.9 \mathrm{mg} / \mathrm{dl}$ ). A clinical diagnosis of iatrogenic calcinosis cutis was made based on the infusion history and the localized calcification. Outpatient surgical intervention was chosen given her severe presentation; however, the patient expired from a fatal arrhythmia while waiting for the procedure. 


\section{Cureus}

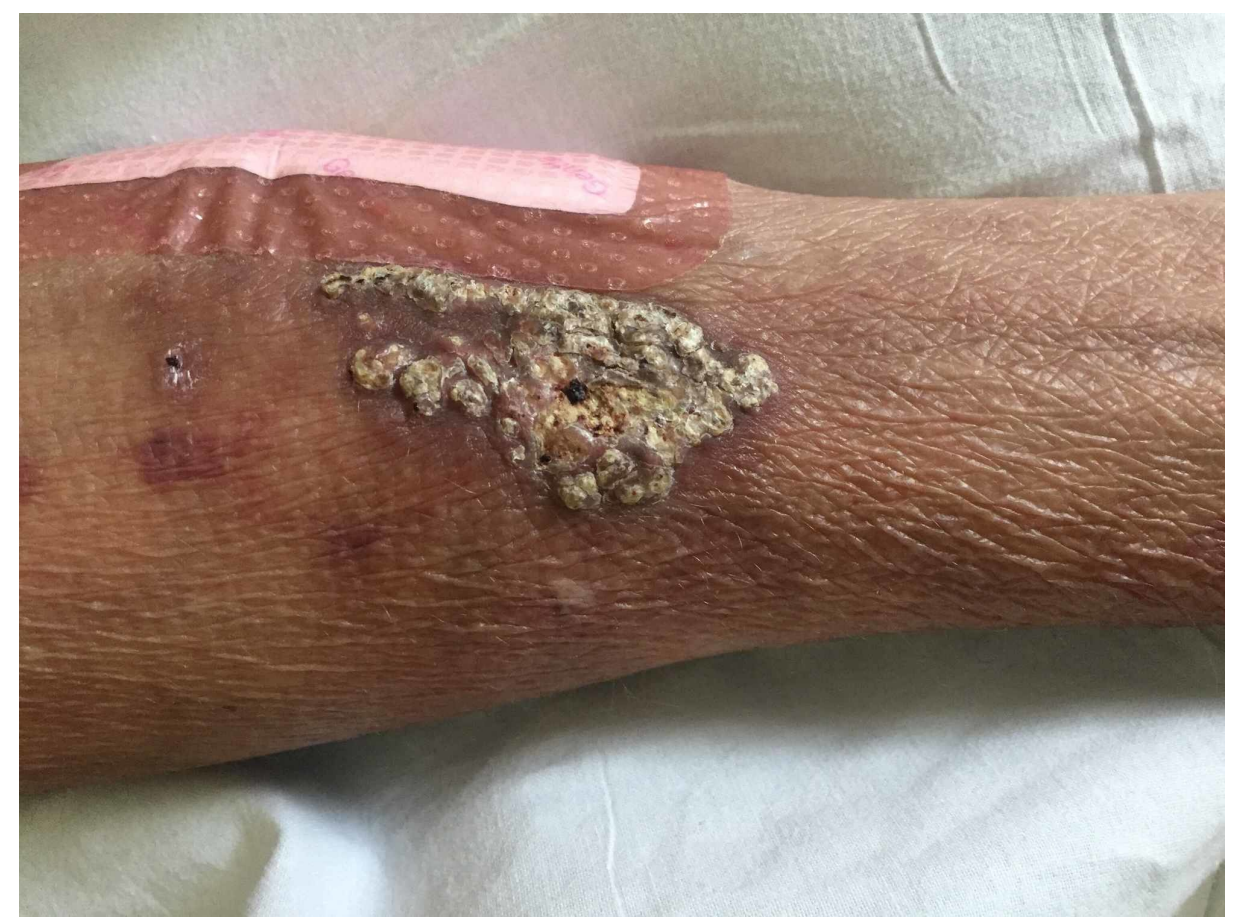

\section{FIGURE 1: Indurated plaque on the right flexor forearm at the site of extravasated calcium gluconate infusion.}

\section{Discussion}

Extravasation of any calcium-containing peripheral infusion can cause iatrogenic calcinosis cutis $[2,3,7]$. Extravasations often lead to abrupt symptoms of erythema, tenderness, induration, and edema; however, subclinical extravasations may lack these initial symptoms and still present with calcinosis. Calcinosis typically develops within two weeks as yellow-white papules, plaques, or nodules with possible tissue necrosis or ulceration. Calcinosis can occur despite removal of the intravenous line suspected of extravasation $[3,7]$.

Subcutaneous injection of calcium-containing solutions in rats led to formation of mineralized plaques with a total calcium content 100 times greater than the amount of calcium infused [8]. Therefore, the hypothesized pathogenesis of iatrogenic calcinosis cutis is mineralization of calcium derived from extravasated calcium solutions and cellular release of calcium from local tissue damage [3,8-10]. This mechanism may explain the development of iatrogenic calcinosis cutis in subclinical extravasations and the variability in degree of calcinosis among patients. An elevated calcium-phosphate product is most associated with metastatic calcinosis cutis and calciphylaxis [1,2]. However, authors have suggested an elevated calcium-phosphate product may increase susceptibility to iatrogenic calcinosis cutis, which may have contributed to our patient's severe calcinosis [9]. Lastly, the presence of collagen, which facilitates calcium phosphate deposition, is believed to be a critical factor in the pathogenesis of iatrogenic calcinosis cutis. Histologic samples of affected tissue show calcium deposits in close proximity to degenerated collagen fibers within the dermis $[3,10]$.

Prevention of extravasation is the most important mitigating factor in developing iatrogenic calcinosis cutis. Use of a central line or diluted calcium and phosphate solutions may reduce rates of iatrogenic calcinosis cutis [9]. Calcium chloride, an inorganic calcium salt, has a higher risk of skin necrosis and adverse effects from extravasation compared to calcium gluconate, an organic calcium salt [11,12]. Theories suggest this heightened risk from calcium chloride is most related to increased dissociation tendency and thus elevated local ionized calcium concentration $[11,12]$. Local ionized calcium concentration appears to be of greater significance than other factors such as $\mathrm{pH}$ or osmolarity $[12,13]$.

Immediate management of clinically recognized extravasations is not well defined. Intralesional triamcinolone acetonide and hyaluronidase was shown to reduce severity and rate of development of calcinosis cutis following extravasated calcium-containing solutions in rabbit models [14,15]. However, there is scant human evidence for these therapies, and conservative measures, such as elevation of the extravasation site and cold compresses, predominate in current practice $[11,16]$.

There is no standardized treatment for iatrogenic calcinosis cutis once it occurs [16,17]. Treatment regimens are largely derived from case reports. Options include conservative, pharmacologic, or surgical management. 


\section{Cureus}

Typically, less severe cases of iatrogenic calcinosis cutis resolve in two to six months with conservative local wound care alone [3]. Sodium thiosulfate, a medication utilized systemically for calciphylaxis or locally for dystrophic calcification, has cation chelating properties allowing for soluble calcium thiosulfate complex formation [9]. Two separate case reports, including a six-year-old boy and a sixty-year-old man with iatrogenic calcinosis cutis, describe topical sodium thiosulfate treatment leading to complete resolution of calcinosis cutis as described in Table $1[9,18]$. There are no other effective pharmacologic therapies studied specifically for iatrogenic calcinosis cutis. Other pharmacologic options are derived from treating different forms of calcinosis cutis, including bisphosphonates, diltiazem, warfarin, minocycline, ceftriaxone, aluminum hydroxide, probenecid, intralesional corticosteroids, and intravenous immunoglobulin $[9,11,17]$. Severe cases, such as our case patient, require surgical intervention $[2,3]$.

\begin{tabular}{|c|c|}
\hline $\begin{array}{l}\text { Author, year of } \\
\text { publication }\end{array}$ & García-García et al., 2017 [9] \\
\hline Patient & Six-year-old boy \\
\hline $\begin{array}{l}\text { Past medical } \\
\text { history }\end{array}$ & $\begin{array}{l}\text { Permanent hypoparathyroidism from } \\
\text { prophylactic thyroidectomy due to carrier } \\
\text { status of RET proto-oncogene and family } \\
\text { history of multiple endocrine neoplasia type } \\
2\end{array}$ \\
\hline $\begin{array}{l}\text { Reason for } \\
\text { presentation }\end{array}$ & Severe hypocalcemia \\
\hline Inciting agent & Intravenous calcium gluconate \\
\hline $\begin{array}{l}\text { Location of } \\
\text { infusion and } \\
\text { initial signs } \\
\text { and symptoms }\end{array}$ & $\begin{array}{l}\text { Left antecubital fossa infusion led to phlebitis } \\
\text { prompting removal and placement in right } \\
\text { antecubital fossa which also led to phlebitis }\end{array}$ \\
\hline $\begin{array}{l}\text { Time to notice } \\
\text { iatrogenic } \\
\text { calcinosis cutis }\end{array}$ & $\begin{array}{l}\text { Bilateral calcinosis occurred within a few } \\
\text { days of infusion }\end{array}$ \\
\hline $\begin{array}{l}\text { Description of } \\
\text { iatrogenic } \\
\text { calcinosis cutis } \\
\text { lesion }\end{array}$ & $\begin{array}{l}\text { On bilateral antecubital fossae, multiple } \\
\text { erythematous nodules with extrusion of } \\
\text { yellow calcified substance }\end{array}$ \\
\hline $\begin{array}{l}\text { Symptoms at } \\
\text { time of } \\
\text { recognizing } \\
\text { iatrogenic } \\
\text { calcinosis cutis }\end{array}$ & Severe motility impairment and pain \\
\hline Treatment & $\begin{array}{l}\text { Compounded } 10 \% \text { topical sodium thiosulfate } \\
\text { in a water-in-oil emulsion cold cream applied } \\
\text { every morning and night under occlusion }\end{array}$ \\
\hline $\begin{array}{l}\text { Therapeutic } \\
\text { course }\end{array}$ & $\begin{array}{l}\text { After three months of treatment: dramatic } \\
\text { improvement in skin lesions and motility. } \\
\text { After six months of treatment: normal skin } \\
\text { appearance and motility }\end{array}$ \\
\hline $\begin{array}{l}\text { Adverse } \\
\text { effects }\end{array}$ & None reported \\
\hline
\end{tabular}

Abbott et al., 2020 [18]

Sixty-year-old man

Chronic obstructive pulmonary disease on tacrolimus for rightsided lung transplant three months prior to case presentation date

Cardiac arrest secondary to a complicated bronchoscopy

Intravenous calcium chloride

Left dorsal hand. No initial signs or symptoms as patient required immediate intubation due to cardiac arrest

Two weeks following infusion after patient was extubated

On left dorsal hand, $4 \times 3 \mathrm{~cm}$ white sclerotic plaque

Asymptomatic

Compounded $10 \%$ topical sodium thiosulfate lotion applied twice daily under occlusion

After one month of treatment: $95 \%$ reduction in plaque size. After two months of treatment: $99 \%$ plaque resolution. At four-month assessment (after an additional one to two weeks of focal applications to residual white spots): complete resolution

None reported

TABLE 1: Comparison of two published cases of iatrogenic calcinosis cutis successfully treated with topical sodium thiosulfate

\section{Conclusions}

Iatrogenic calcinosis cutis is an uncommon manifestation most commonly occurring after extravasation of calcium-containing solutions. Clinicians should be aware of the variable time course and severity resulting 
from either clinically insignificant or noticeable extravasations. Treatment should be considered immediately after extravasations and upon development of calcinosis cutis. However, no agreed upon treatment protocol for these clinical scenarios exists.

\section{Additional Information \\ Disclosures}

Human subjects: Consent was obtained by all participants in this study. Conflicts of interest: In compliance with the ICMJE uniform disclosure form, all authors declare the following: Payment/services info: All authors have declared that no financial support was received from any organization for the submitted work. Financial relationships: All authors have declared that they have no financial relationships at present or within the previous three years with any organizations that might have an interest in the submitted work. Other relationships: All authors have declared that there are no other relationships or activities that could appear to have influenced the submitted work.

\section{References}

1. Reiter N, El-Shabrawi L, Leinweber B, Berghold A, Aberer E: Calcinosis cutis: part I. Diagnostic pathway. J Am Acad Dermatol. 2011, 65:1-12. 10.1016/j.jaad.2010.08.038

2. Jiménez-Gallo D, Ossorio-García L, Linares-Barrios M: Calcinosis cutis and calciphylaxis. (Article in En, Spanish). Actas Dermosifiliogr. 2015, 106:785-794. 10.1016/j.ad.2015.09.001

3. Moss J, Syrengelas A, Antaya R, Lazova R: Calcinosis cutis: a complication of intravenous administration of calcium glucanate. J Cutan Pathol. 2006, 33:60-62. 10.1111/j.1600-0560.2006.00519.x

4. Schoenfeld RJ, Grekin JN, Mehregan A: Calcium deposition in the skin; a report of four cases following electroencephalography. Neurology. 1965, 15:477-480. 10.1212/wnl.15.5.477

5. Johnson RC, Fitzpatrick JE, Hahn DE: Calcinosis cutis following electromyographic examination . Cutis. 1993, 52:161-164.

6. Wiley HE 3rd, Eaglstein WE: Calcinosis cutis in children following electroencephalography . JAMA. 1979, 242:455-456. 10.1001/jama.1979.03300050045027

7. Domínguez-Fernández I, Goíriz R, Pérez-Gala S, Fraga J, Fernández-Herrera J: Calcinosis cutis following extravasation of calcium salts. J Eur Acad Dermatol Venereol. 2008, 22:505-506. 10.1111/j.14683083.2007.02369.x

8. Leonard F, Boke JW, Ruderman RJ, Hegyeli AF: Initiation and inhibition of subcutaneous calcification . Calcif Tissue Res. 1972, 10:269-279. 10.1007/BF02012558

9. García-García E, López-López R, Álvarez-Del-Vayo C, Bernabeu-Wittel J: Iatrogenic calcinosis cutis successfully treated with topical sodium thiosulfate. Pediatr Dermatol. 2017, 34:356-358. 10.1111/pde.13116

10. Goldminz D, Barnhill R, McGuire J, Stenn KS: Calcinosis cutis following extravasation of calcium chloride . Arch Dermatol. 1988, 124:922-925. 10.1001/archderm.1988.01670060068019

11. Reynolds PM, MacLaren R, Mueller SW, Fish DN, Kiser TH: Management of extravasation injuries: a focused evaluation of noncytotoxic medications. Pharmacotherapy. 2014, 34:617-632. 10.1002/phar.1396

12. Heckler FR, McCraw JB: Calcium-related cutaneous necrosis. Surg Forum. 1976, 27:553-555.

13. Semple P, Booth C: Calcium chloride; a reminder. Anaesthesia. 1996, 51:93. 10.1111/j.13652044.1996.tb07673.x

14. Ahn SK, Kim KT, Lee SH, Hwang SM, Choi EH, Choi S: The efficacy of treatment with triamcinolone acetonide in calcinosis cutis following extravasation of calcium gluconate: a preliminary study. Pediatr Dermatol. 1997, 14:103-109. 10.1111/j.1525-1470.1997.tb00214.x

15. Laurie SW, Wilson KL, Kernahan DA, Bauer BS, Vistnes LM: Intravenous extravasation injuries: the effectiveness of hyaluronidase in their treatment. Ann Plast Surg. 1984, 13:191-194. 10.1097/00000637198409000-00003

16. Le A, Patel S: Extravasation of noncytotoxic drugs: a review of the literature . Ann Pharmacother. 2014, 48:870-886. 10.1177/1060028014527820

17. Reiter N, El-Shabrawi L, Leinweber B, Berghold A, Aberer E: Calcinosis cutis: part II. Treatment options . J Am Acad Dermatol. 2011, 65:15-22. 10.1016/j.jaad.2010.08.039

18. Abbott J, Kowalski EH, Klein S, DeShazo R, Hull CM: Iatrogenic calcinosis cutis secondary to calcium chloride successfully treated with topical sodium thiosulfate. JAAD Case Rep. 2020, 6:181-183. 10.1016/j.jdcr.2019.12.017 